Article

\title{
Risk Reduction Methods for Managing the Development of Regional Electric Power Industry
}

\author{
Mikhail Kozhevnikov $^{1}$ (D), Lazar Gitelman ${ }^{1}$, Elena Magaril ${ }^{2, *}$ (D), Romen Magaril ${ }^{3}$ \\ and Alexandra Aristova ${ }^{2}$ \\ 1 Department of Management Systems for Energy and Industrial Enterprises, Ural Federal University, \\ Mira str., 19, 620002 Ekaterinburg, Russia; m.v.kozhevnikov@urfu.ru (M.K.); ldgitelman@gmail.com (L.G.) \\ 2 Department of Environmental Economics, Ural Federal University, Mira str., 19, 620002 Ekaterinburg, \\ Russia; aai89@mail.ru \\ 3 Department of Oil and Gas Processing, Tyumen Industrial University, Volodarskogo str., 38, 625000 Tyumen, \\ Russia; magaril7@yandex.ru \\ * Correspondence: magaril67@mail.ru; Tel.: +7-912-63-98-544
}

Received: 27 October 2017; Accepted: 27 November 2017; Published: 29 November 2017

\begin{abstract}
The development of the regional electric power industry has come to the forefront due to the changing scale, quality, and configuration of electric power infrastructure, and the spread of distributed generation. This gives rise to more stringent requirements regarding the reliability, safety, and environmental impact of electric power supply. This article aims to justify a package of methods that make it possible to identify and minimize investment, production, financial, and environmental risks in order to ensure sustainable development of the regional electric power industry that performs anti-crisis functions, and of individual energy companies. The key method to be employed is integrated resource planning (IRP). As a part of the method, energy conservation, renewable energy sources, and combined heat and power production are considered as equally valid ways of meeting future demand. The authors have designed a methodology for taking into account uncertainty and risk when implementing IRP. The methodology includes analysis of scenarios and decision making processes by calculating past and projected values of profit indicators. When conducting the environmental and economic assessment of an investment project in the electric power industry, the authors suggest using an aggregate indicator of environmental and economic effectiveness that is calculated on the basis of a combination of locally significant positive and negative environmental and economic impacts of the project. The authors formulate conceptual provisions that serve as the foundation for a promising model of the regional electric power industry and which contain recommendations for managing the development of the industry while minimizing organizational, market, and technological risks.
\end{abstract}

Keywords: regional electric power industry; energy policy; integrated resource planning; risk management; environmental and economic assessment; technology modernization

\section{Introduction}

Regional electric power industry consists of various types of distributed generation installations that are located in the closest possible proximity to consumers, as well as of power transmission facilities of the region. The regional electric power industry typically includes small and medium-sized co-generation units (CHP plants) - with their capacity ranging from less than 10 to less than 100 megawatts-as well as unconventional renewable energy sources of various types: small hydroelectric power plants, wind turbines, solar energy, biomass installations, etc. [1].

Studies into the problem of risk management in the course of the development of electric power industry are usually area-specific. In this context, the main goal is the reduction of risks 
during the process of energy supply planning and development of regional energy infrastructure programs. Some studies look at issues associated with the reduction of risks in the logistics and siting of new power generation installations [2-4]; electrification of remote areas [5-9]; environmental efficiency [10,11]; information security and cybersecurity [12,13]; and investment provisions of overhaul and technological upgrade of power installations $[14,15]$.

The most comprehensive approach can be found in $[16,17]$. They describe the regional electric power industry that forms "critical energy infrastructure" as a complex system with appropriate emergent behavior. The key task of risk management is to maintain the system's balance, ensuring its safety by identifying weak signals and prevention of force majeure. The "complexity" of the systems stems not only from its architecture, in which stakeholders with various groups of interests interact, but also from the presence of innovative and all too often competing energy technologies $[18,19]$. This gives rise to the task of multicriteria optimization in line with investment, technological, and environmental criteria.

A special group of risks to the development of the regional electric power industry are risks associated with energy companies' and major producers' activity on energy markets and formation of appropriate behavior strategies [20-23]. The authors of [20] say, for example, that the key task is to reduce the risks of faced by suppliers operating on the wholesale and retail electricity market because price volatility, demand uncertainty, and imperfect mechanisms of bidding are directly linked to the worsening of the investment climate in the region's electric power industry. The authors suggest solving the problem by having a system of risk control in place.

Compared to other individual methods that various authors employ for studying the problems in the field (the spectrum of research is rather broad, including the creation of early threat detection systems, maps (profiles) of risks; corporate information systems; various mathematical algorithms, etc.), the mechanisms of regional energy policy play the role of an institutional solution that, among other things, help reduce industry-specific risks. This includes the creation of effective administration and management of communications among authorities, energy companies, consumers, energy suppliers, and financial and legal institutions. The mechanism is outlined in [24-26].

In general, one has to note that the key trend in the development of the electric power industry is taking shape under the influence of factors with essential degree of uncertainty. Among them are the pace of economic growth or economic decline, demand for energy, investment constraints, and prices of fossil and nuclear fuels. In such conditions, the focus on the construction of large power plants might result in recurring local crises in some regions of the country marked by capacity shortages, volatile electricity and heat prices, and irrational use of fuel and energy resources. These are the direct effects of a contradiction between the probabilistic assessment of the above mentioned factors and the economic inertia of the grid industry. Under these conditions, the search for optimal proportions between the introduction of distributed power systems based on small generation (solar, wind, biofuels) and large scale power generation taking into account investment and technological risks begins to gain in importance.

Primary importance, therefore, goes to the task of minimization of not only local operational risks [27-29], but first and foremost to strategic risks [1] that impact on the infrastructural preparedness of the region to the introduction of new organizational, technological, and architectural solutions. The configuration of the electric power industry is changing so fast and at such a large scale that it is necessary to design special methods of mitigation of such risks and their integration into a unified system. This determines the relevance and tasks of this research that seeks to design a comprehensive approach to the assessment and management of risks to the sustainable development of the regional electric power industry and individual energy companies.

\section{Materials and Methods}

The authors used a mix of scientific methods for carrying out an in-depth analysis of the electric power industry and development trends in the structure of the energy program of a region. During the 
first phase, it was necessary to identify the content of the region's energy policy that determines the choice of appropriate instruments for the development of the regional electric power industry, and the feasibility of their use and implementation restrictions within the industry by individual companies and by consumers. The informational basis for the study was provided by data from international consulting companies [30-34], scientific papers on various aspects of building an energy policy [35-50]. The theoretical and summative analysis that was performed made it possible to formulate the key tasks of the energy policy and reveal a number of its significant features that determine its contribution to mitigation of industry-specific risks.

Having determined that the regional energy policy provides a sufficiently broad field for risk management, during the second phase the authors selected appropriate instruments that are of the greatest interest to both government bodies and the real sector. The authors conducted a survey and interviews of competent experts in various organizations and at various levels of authority: industrial ministries and major energy companies of the Ural region of Russia-from department leads to chief engineers and energy scholars at Ural Federal University (Figure 1).
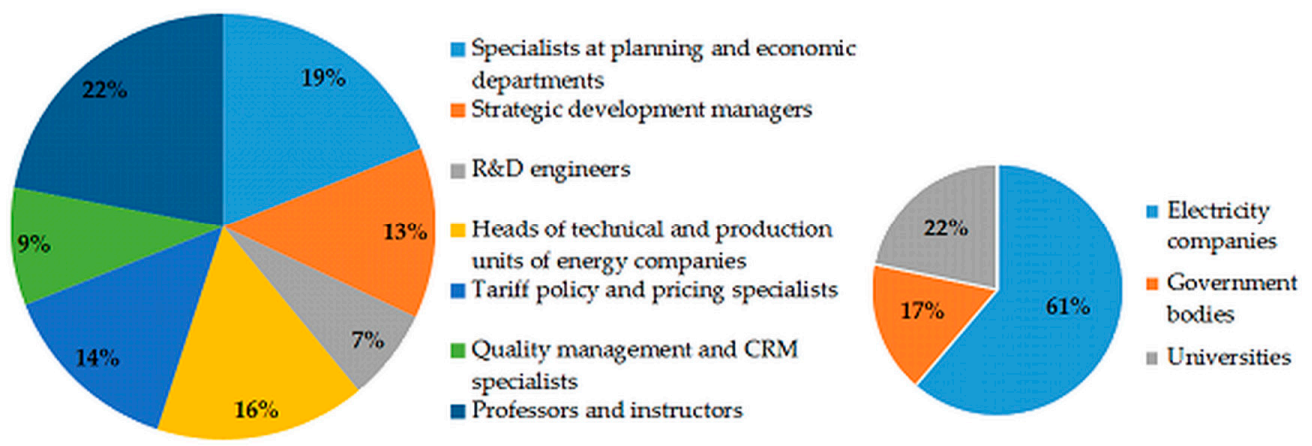

Figure 1. Composition of specialists who were surveyed for purpose of selecting instruments.

The theoretical aspects of the integrated resource planning method were revealed by using the abstract logical method that made it possible to identify important logical links and characteristics in a series of processes and phenomena. Management and sustainable development practices in the energy sector were applied [51] that take into account the analysis of uncertainty and risk. A systemic-structural approach was combined with an economic-mathematical method for the purpose of identifying structural changes in the traditional model of risk management and economic account of risk events. A general scientific systemic approach, and structural and logical analysis were used for integration of the components of the economic and environmental impacts when assessing the effectiveness of investment projects in the industry. In order to design a promising organization model for the electric power industry of a major region, a systemic approach and a method of conceptual design were employed that had been developed by the authors [52].

\section{Results and Discussion}

\subsection{Design of Energy Policy for Risk Reduction in Managing the Regional Electric Power Industry}

The first theoretical task of the study was building a framework within which the regional energy policy functions as an instrument of institutional support for the implementation of specific risk management methods. An analysis of the relevant publications points to a wide range of tasks that could be addressed as part of the energy policy: design of integrated markets of energy and utility services (electricity, gas, water) and ancillary services [35-38]; continuous screening for cutting-edge energy technologies and analysis of options of their introduction from the point of view of energy asset lifecycle management [41,42]; opportunities and options of embracing small-scale installations that boast high investment mobility, technical flexibility, environmental and economic effectiveness, and a synchronizable launch with an increase in electrical loads in the area $[43,44]$; minimization of the 
environmental impact along the entire chain of power generation [45-50]. The relevance of the latter task has to do with the fact that the energy sector is the major source of greenhouse gas emissions (Figure 2) and plays a major role in human impact on the environment.

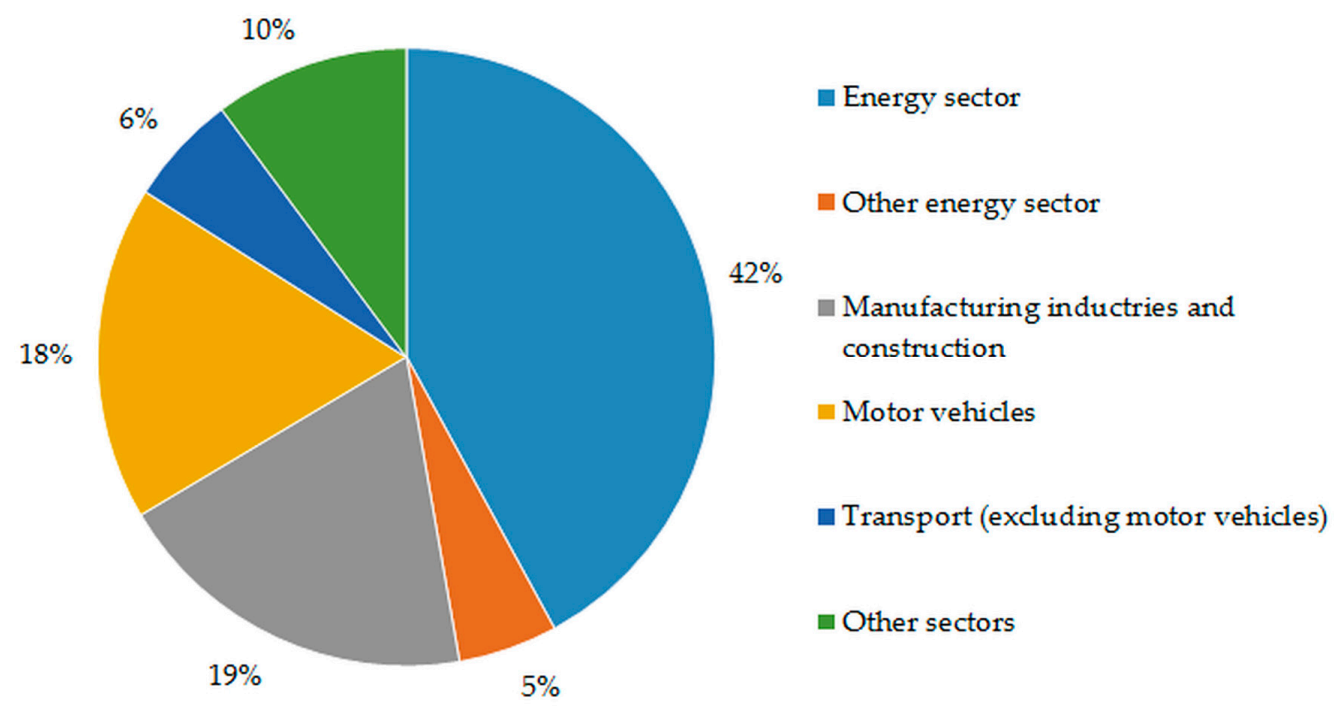

Figure 2. Overall world emissions of $\mathrm{CO}_{2}$ in different sectors 2014 (based on data from [50]).

Consequently, the role of energy policy is to provide for socio-economic development of the region by ensuring reliable power supply while using a minimum amount of resources and having a minimum impact on the environment under conditions of changing external factors-economic, political, social, technological, and environmental.

The authors believe that an implementation model for the regional energy policy focused on the minimization of industry-specific risks should contain a cluster of goals and priorities and a system of measures aimed at preventing the localization of negative occurrences in the regional electric power industry. The measures should be devised on the basis of the analysis of factors and forms of energy crisis. The authors divide the negative occurrences into endogenic (intrinsic to the industry) and exogenic (external) ones. Such division is necessary for comprehensive prevention and localization of the negative occurrences (Table 1). The combination of the factors and conditions that are systematized in Table 1, show, on the one hand, the depth and duration of the crisis, and, on the other hand, possible ways out of it. The identified factors and forms of crisis phenomena in the electric power industry of a region should be countered with specific instruments for mitigation of risks that accompany the development of scenarios and implementation of energy policy (Figure 3).

Table 1. Factors and forms of negative occurrences in regional electric power industry

\begin{tabular}{ccc}
\hline & Type of Factor & Form of Crisis \\
\hline \multirow{3}{*}{ Endogenic } & Excessive wear of assets & Replenishing \\
& $\begin{array}{c}\text { Lack of coordination in energy system development } \\
\text { Irrational structure of energy consumption } \\
\text { Environmental pollution }\end{array}$ & $\begin{array}{c}\text { Disintegrating } \\
\text { Structural } \\
\text { Environmental }\end{array}$ \\
\hline \multirow{2}{*}{ Exogenic } & $\begin{array}{c}\text { Payment delays } \\
\text { Inflation }\end{array}$ & Financial \\
& Structural shifts in national economy; decline in production & Finvestment \\
& &
\end{tabular}




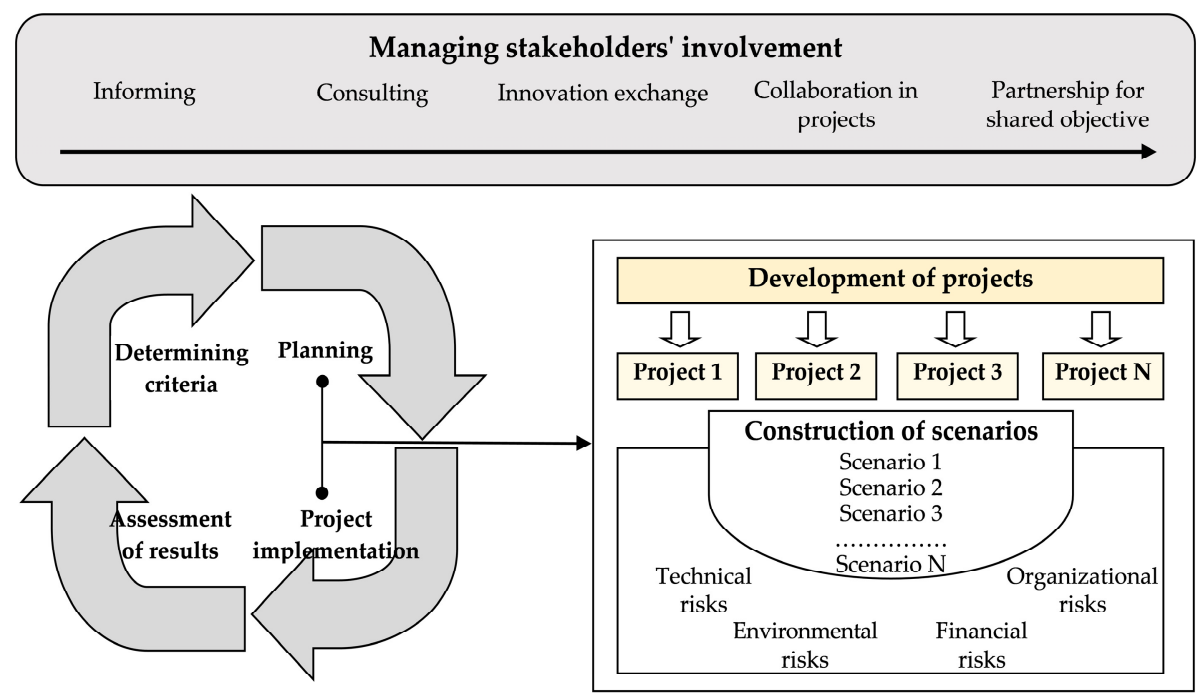

Figure 3. Conceptual framework for energy policy development based on $[53,54]$.

The findings of the authors' survey of competent specialists made it possible to establish priority instruments for risk management in the regional electric power industry (Figure 4). As one can see from the figure, the majority of the interviewees emphasize the importance of introducing the IRP method in energy companies and the regional electric power industry administration. They also point to methods of assessing environmental and economic risks that occur in the course of implementation of investment projects aimed at development. These groups of methods are the most comprehensive ones and take into account both the endogenic and exogenic factors and forms of crisis occurrences in the electric power industry of a region.

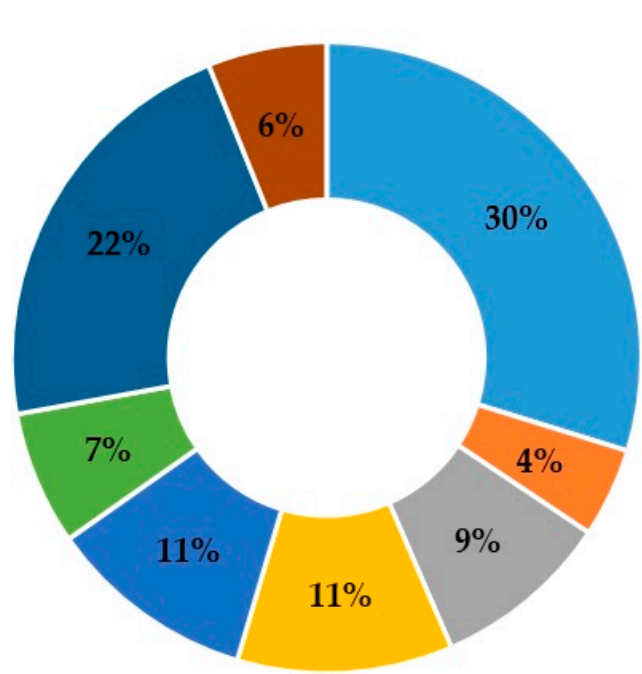

= IRP

- Risk mapping

- Expert methods, panel discussions, thematic symposiums

- Scenario analysis

- Weak signals identification for risk management

- Graphical methods and visual analytics

- Special methods of environmental and economic risk assessment

- Diversification of risks

Figure 4. Instrumental methods for reducing risks in the regional energy sector: request from key stakeholders.

\subsection{Uncertainty and Risk in Integrated Resource Planning}

Integrated resource planning (IRP) is based on a complex approach to energy conservation in both the electric power industry and in end-use energy consumption where the potential of energy conservation is particularly high. The energy company's expenditures on demand-side energy saving programs replace much bigger development expenditures (or the cost of overhauling excessive 
generating capacities). It is noteworthy that the difference in expenditures is the economic basis of IRP and a balance of interests of main participants in the energy market.

The authors' analysis of IRP method application [51,55-60] shows that it is beneficial for all parties concerned: energy companies, consumers of electricity and heat, and the region (Table 2).

Table 2. Positive effects of implementation of an IRP for interested parties.

\begin{tabular}{cl}
\hline Entity & \multicolumn{1}{c}{ Positive Effects } \\
\hline - & $\begin{array}{l}\text { Lower risk of investing in new costly generating capacity amid high } \\
\text { uncertainty about demand for energy. }\end{array}$ \\
Energy company & $\begin{array}{l}\text { Higher sustainability, flexibility, and adaptability of energy systems } \\
\text { thanks to involvement of additional resources—energy conservation in } \\
\text { the first place and renewable energy sources (RES). }\end{array}$ \\
Consumers & - $\begin{array}{l}\text { More reliable power supply of higher quality at lower tariffs for } \\
\text { consumed energy. } \\
\text { Additional technical and financial opportunities of access to advanced } \\
\text { energy efficient technologies. }\end{array}$ \\
\hline Region & Greater energy self-sufficiency (security). \\
\hline
\end{tabular}

In the context of IRP, this shifts the focus to power supply services and the expansion of the network of independent smaller producers and energy saving capacity rather than to power generation. It has to be noted that the entire system of relations between parties involved is undergoing transformation.

For example, electricity producers are moving exclusively to the wholesale market, ending business with end users and low-consumption organizations. This enables them to focus entirely on increasing output and implementing a more effective investment program for finding and adopting new solutions and technologies. Intermediaries work directly with households and smaller customers, undertaking the obligation to offer a wide range of prices and terms and conditions and to create a competitive environment. End users, for their part, get the opportunity to set the development scenarios, being guided by the competitive behavior of intermediaries and plans for infrastructure and industry development that can be found in the public domain.

This structure, on the one hand, delineates the functions and areas of the business, and, on the other hand, plays an integratory role for the entire process. Thus, the method allows for optimizing the energy resources in a comprehensive manner: at the level of transmission, distribution, and provision of energy services to end-users.

The authors have designed a methodology for factoring uncertainty and risks in integrated resource planning. The methodology recognizes relationships between the specific features of the industry and corresponding specific features of risk management. The first phase of the proposed approach is identification of characteristics typical of an industry. In the electric power sector, the list of such characteristics includes:

- ensuring uninterrupted electricity production,

- ensuring constant access to the resource for all business actors, and

- rational accounting of the impact of power supply on the region's development.

The second important phase of uncertainty analysis is identification and distribution of the characteristics described above according to the types of risk. As IRP combines finance and production, the same is done in application to risk.

The third phase envisages integration of the risk and probability of occurrence of a hazardous event. This is the principal difference of the proposed approach from the traditional model, which treats 
risk occurrence in production separately from risk occurrence in finance. The IRP method produces an integrated profile of risks and probabilities of hazardous events and creates its own system of measuring, accounting for and control over current operations at every level of the business process.

In the fourth phase, it is necessary to evaluate potential benefits for the project in case a hazard is avoided. Usually, qualitative and quantitative assessment of potential damage is conducted alongside the assessment of the probability of hazard occurrence [61]. In the suggested approach, the monetary value of the potential benefit appears to be an interactive part of the financial sector that makes it possible to expand the horizons of strategic planning and to monitor interaction between the feedback mechanism within a project and fluctuations of the external environment. Forecasting the environment and adjusting business processes to plans thus becomes an important part of the risk management structure.

The profile of risks was built by drawing upon a list of hazards that are brought about by undesirable consequences. The list might include statistically registered critical occurrences and failures and theoretically possible accidents and incidents. Each event in risk management implies the existence of safeguards for reducing the probability of their occurrence and barriers for limiting the scale of the disaster. A blueprint of integrated risk management is given in Figure 5. In both cases, cost evaluation should be done $(\mathrm{C} 1$ and $\mathrm{C} 2)$ that includes the cost of decision making and the cost of taking action on the basis of the decisions procedurally, construction-wise and program-wise.

1. Procedural decisions are the ones that exclude the human factor as a prerequisite for the occurrence of a hazard or as a result of unintended consequences in the technological process. These include checklists, flow charts, flow diagrams, and process flow charts that codify the sequence of action.

2. Construction solutions are physical safeguards for reducing the likelihood of a hazard or mitigating its aftermath.

3. Program solutions are safeguards that are created thanks to automation of production processes and the use of information technology for accuracy and precision of decision making [62].

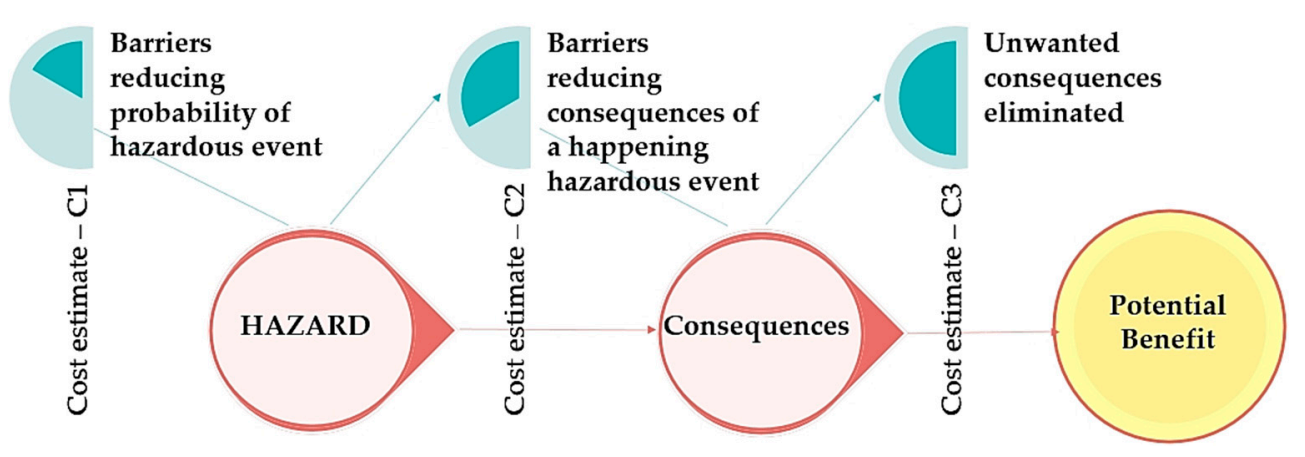

Figure 5. Integrated resource planning chart.

A risk event can have a number of consequences, with each of them being considered and calculated separately in terms of four universally accepted categories: capital, environment, personnel, and reputation. The cost value (C3), associated with responding to unwanted consequences of a hazardous event and their mitigation when all existing preventive barriers failed, is generally viewed as the company's losses, whereas the absence of the losses has not been financially expressed before.

The integrated approach to risk management implies the continuity of risk accounting and control as well as uninterrupted monitoring of current operations and of the environment in order to identify potential events capable of reducing or increasing the effectiveness of the project. This system makes it important to calculate potential benefit $(P B)$ as a factor determining development trends. 
The authors suggest that potential benefit should be calculated as a difference between the sum total of the costs of eliminating the consequences of the hazard and the costs of having safeguards for preventing the occurrence of the hazard and all its consequences.

$$
P B=\sum_{i=1}^{m} C 3-\sum_{i=1}^{n} C 2-\sum_{i=1}^{k} C 1
$$

where $C 3$ is the cost of the system recovery to its intended state after unwanted consequences have happened, expressed in currency units; $m$ is the number of consequences that need to be rectified after the hazard; $C 2$ is the cost of having a safeguard for reducing the scale of the consequence, expressed in currency units; $n$ is the total number of safeguards for reducing the scale of the consequences; $C 1$ is the cost of the safeguard for reducing the likelihood of the occurrence of the hazard, expressed in currency units; $k$ is the total number of barriers for reducing the likelihood of the occurrence of the unintended event.

The value of $P B$ is calculated and recorded regardless of the occurrence of the risk event and despite a negative or a positive outcome. This creates a database and a system of measures, coefficients, and errors that serve as the basis for making more balanced decisions and forming management methods for future events.

\subsection{Assessment of Environmental and Economic Effectiveness of Investment Projects in the Electric Power Sector}

Any project that envisages qualitative and quantitative structural shifts in the regional electric power supply requires an integrated approach to assessment that takes into account all significant environmental and economic factors. This makes it possible to factor in all costs and benefits when making managerial decisions. To do that, a procedure is required that consolidates economic and environmental outcomes as well as economic costs and environmental impacts (external effects). Moreover, the effect of implementing investment projects aimed at reforming and overhauling regional power supply facilities should take into account both positive results and negative outcomes. It has to be noted that, when accounting for the time factor in the economic and environmental components, one should use differentiated discount factors $\left(r_{e n}\right.$ and $r_{e l}$ respectively, with $\left.r_{e l}<<r_{e n}\right)$ in order to increase the significance of the environmental factor when calculating integral environmental and economic effectiveness. It should be noted that the adequate determination of the discount coefficients $r_{e n}$ и $r_{e l}$ is the subject for a separate serious study.

Consequently, the basic principles of investment project evaluation in the energy sector are the following:

1. An integral approach to accounting for positive effects and negative consequences of investment project implementation.

2. The economic and environmental components of costs and benefits should be treated equally. This makes it possible to convert the environmental component into an economic category.

3. A differentiated approach to accounting for the time factor in the economic and environmental components of benefits and costs.

Equation (2) is proposed to be used for assessing the environmental and economic effectiveness of implementing an investment project aimed at upgrading a regional electric power facility, $E_{e e}$, making use of differentiated discount factors:

$$
E_{e e}=\frac{\sum_{t=1}^{k} \frac{1}{\left(1+r_{e n}\right)^{t}} \sum_{i=1}^{n}\left(B_{e n_{i}}-C_{e n_{i}}\right)+\sum_{t=1}^{k} \frac{1}{\left(1+r_{e l}\right)^{t}} \sum_{i=1}^{n}\left(B_{e l_{i}}-C_{e l_{i}}\right)}{\sum_{t=1}^{k} \frac{1}{\left(1+r_{e n}\right)^{t}} \sum_{i=1}^{n} C_{e n_{i}}+\sum_{t=1}^{k} \frac{1}{\left(1+r_{e l}\right)^{t}} \sum_{i=1}^{n} C_{e l_{i}}}
$$


where $B_{e n_{i}}$ are positive economic outcomes-various components of income, including the target economic result of the project, and a set of concomitant beneficial economic results, expressed in currency units; $B_{e l_{i}}$ are positive environmental outcomes, including the prevented environmental damage to the atmospheric air, water, land resources, expressed in currency units; $C_{e n}$ are additional costs that represent a sum of financial expenditures and utilized materials, required for the project implementation (economic costs) and the value of the lost profit expressed in currency units; $C_{e l_{i}}$ is the cost of the entire combination of all negative environmental consequences of the project-environmental damage to the atmospheric air, water, land resources, caused by the project, expressed in currency units; $n$ is the total number of consequences; $t$ is the number years from which the expenditures and outcomes are discounted back to the starting year of the project $(1 \leq t \leq k)$.

When assessing the negative environmental impacts of a facility, air and water pollution as well as damage to the land and subsoil resources are taken into account.

Given the difficulty of taking full account of externalities, it is necessary to design and apply appropriate simplified approaches to assessing the effectiveness of alternative investment projects. This indicates the directions of further research in this field. One of the options is to take into account only the positive effects and negative consequences in Equation (2) that are of the highest importance to the region being considered. These effects should be selected on the basis of expert evaluation.

Figure 6 depicts the authors' algorithm of conducting an assessment of the environmental and economic effectiveness of implementing an investment project aimed at overhauling a regional electric power facility.

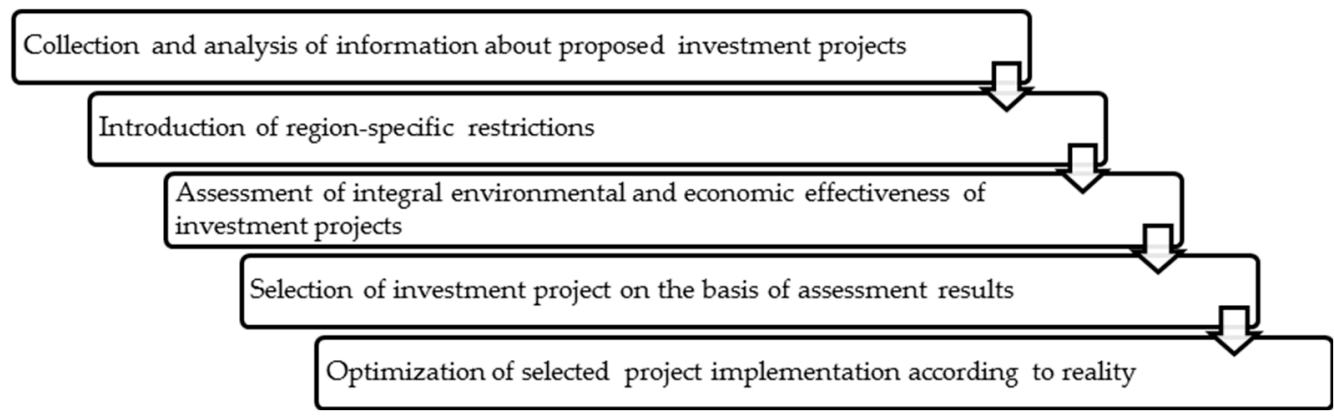

Figure 6. Algorithm for assessing environmental and economic effectiveness of implementing an investment project of overhauling a regional electric power facility.

\subsection{Promising Model of the Electric Power Sector in a Large Region}

As a result of summarizing the results of theoretical works [63-66], conducting discussions, and expert sessions with the participation of heads of energy companies and the authors' own research [1,67-69], the following conceptual positions were formulated which form the foundation of the promising model of the regional electric power industry.

When drawing the boundaries of the region, a combination of economic, energy, and administrative and political factors are supposed to take effect. The boundaries of a unified energy system (UES) coincide with the boundaries of a large economic region. A UES should be self-balancing in terms of capacity and load. Adjacent UESs should have emergency direct current links of sufficient capacity. These links can, of course, be used for commercial purposes, but that would be an exception to the rule.

In this case, the regional structure of power generating capacity and functions of individual energy clusters include:

- Cluster one: large power plants that are merged into an electric power system (serving large energy intensive consumers with an even load schedule) for discretionary loads-for example in the machine building industry—demand-side management on the part of major energy companies; 
- Cluster two: distributed generation installations with uneven load schedules are 'assigned' to electricity-non-intensive consumers, for example in the utilities sector or agriculture.

Power plants belonging to the second cluster should offer a lower cost of service to its consumers than power plants in the first cluster. This creates conditions for minimizing parameters of power supply in terms of cost and time along with a reduction in prices charged to all groups of consumers (considering the economic advantages of distributed generation installations). Price optimization at a regional level is done by the technological operator of the UES by distributing the load among power plants in cluster one. System reliability and power supply reliability is ensured by the power plants in cluster one together with grids at a minimum (possibly regulated) cost for all consumers in the region (within the UES).

Major industrial consumers can build off-grid power generators or enter into direct contracts with utilities operating in the region, thus taking on some of the risks to power supply reliability (another portion of the risks is accepted by the energy company). The price of power generation that has been agreed upon should not exceed the price yielded by dispatch control optimization.

The regional electric power sector is governed in line with the scheme presented in Figure 7. The central governing body is the regional council. It creates the framework of the energy policy in the region that is implemented through relevant programs, plans, and power supply layouts.

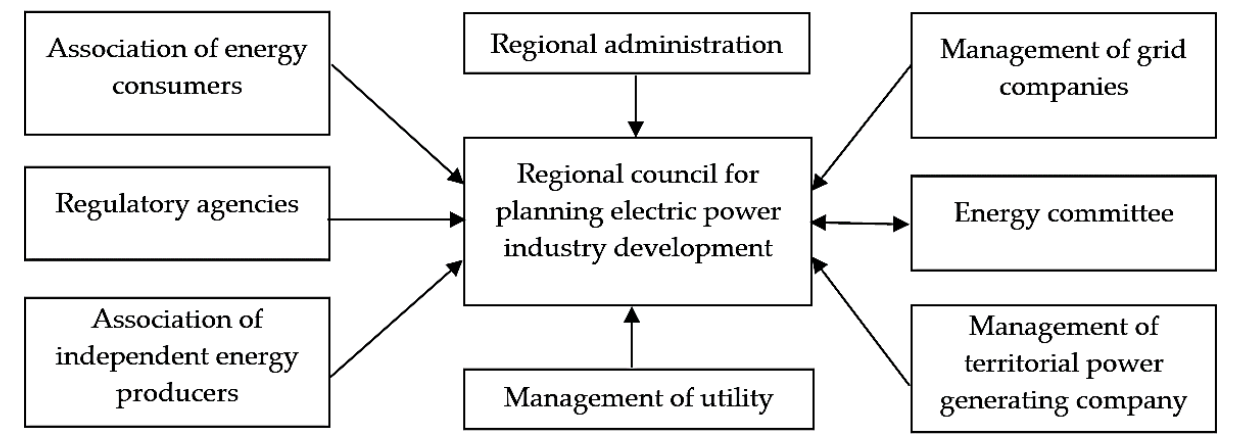

Figure 7. Structure of governance in regional electric power industry.

The motivational mechanism of the regional electric power sector is aimed at fulfilling such priorities of the energy policy as engaging regional energy companies in efficient energy use efforts, creating competition in the regional industry, and attracting investments in the electric power industry undergoing modernization. These priorities form a set of the main elements of the motivational mechanism, among which the most relevant are $[1,9,67,69]$ :

- Guidelines standardizing the characteristics of new and renovated combined heat and power plants (CHP);

- Tax incentives to encourage investment in energy installations that meet the accepted standards and priorities of the technological policy;

- Use of accelerated depreciation for taxation purposes at new advanced installations; guarantees of sales and acceptable return on capital to owners of "green" RES installations and micro-CHP plants;

- Encouraging energy efficiency and reduction of operating costs by setting target volumes of necessary gross revenue (NGR) and by using the method of NGR distribution that takes into account the impact of combined-cycle production on electricity and heat prices;

- Stimulation of cooperation between regional energy companies and consumers of electricity and heat as part of demand side management programs, for example, by sharing savings from energy efficiency measures. It is also advisable to have targeted tax incentives in place that energy companies would be entitled to if they invest in rationalizing the energy infrastructure of consumers. 
Naturally, the more comprehensive the implementation of the above proposals is, the faster and more effective the result will be.

\section{Conclusions}

The authors have designed a promising organizational model for the electric power industry of a large region. The study substantiates anti-crisis (stabilizing) functions of regional electric power industry that ensures prompt introduction into service of generating capacity and maximum effectiveness of energy resource utilization, maintains high reliability of power supply, and reduces price risks for consumers.

It is proposed to consider the regional energy policy as an institutional instrument for reducing risks when managing the development of the regional electric power industry. Regional energy policy contains a system of measures aimed at preventing the occurrence of negative endogenic and exogenic factors and forms of energy crisis that determine a mix of tools to be used for mitigation of relevant risks. In this regard, the authors prove that the basic tool of energy policy is the IRP method, which makes it possible to manage the risk problem in a complex systemic way. This comes to the fore due to the qualitative transformation of energy infrastructure (distributed generation, smart environments, production, transport, and logistics systems).

The authors suggest that a combination of methods should be used when analyzing uncertainty and risks in the integrated resource planning process. By integrating various risk events into one whole by means of a combination of the qualitative and quantitative methods, it will be possible to expand the planning horizon and optimize investment projects.

The basic principles and phases of conducting integral assessment of the environmental and economic effectiveness of investment projects in the electric power industry have been formulated. Given the difficulty of detecting all emerging external effects, the authors suggest using a simplified approach that takes into account positive and negative effects of the highest importance to the region where the project is implemented.

Acknowledgments: The work was supported by Act 211 of the Government of the Russian Federation, contract No. 02.A03.21.0006.

Author Contributions: All authors contributed equally to research, presented in this paper.

Conflicts of Interest: The authors declare no conflict of interest.

\section{References}

1. Gitelman, L.D.; Bokarev, B.A.; Gavrilova, T.B.; Kozhevnikov, M.V. Anti-Crisis Solutions for Regional Energy Sector. Econ. Reg. 2015, 3, 173-188. [CrossRef]

2. Liu, B.; Wu, Q.; Wang, F. Regional optimization of new straw power plants with greenhouse gas emissions reduction goals: A comparison of different logistics modes. J. Clean. Prod. 2017, 161, 871-880. [CrossRef]

3. Ruiz, N.; Cobelo, I.; Oyarzabal, J. A direct load control model for virtual power plant management. IEEE Trans. Power Syst. 2009, 24, 959-966. [CrossRef]

4. Ionescu, R.D.; Ragazzi, M.; Battisti, L.; Rada, E.C.; Ionescu, G. Potential of electricity generation from renewable energy sources in standard domestic houses. WIT Trans. Ecol. Environ. 2013, 176, 245-253. [CrossRef]

5. Otsuka, A. Regional Energy Demand and Energy Efficiency in Japan an Application of Economic Analysis; Springer International Publishing: Cham, Switzerland, 2017; 98p.

6. Baldwin, E.; Brass, J.N.; Carley, S.; MacLean, L.M. Electrification and rural development: issues of scale in distributed generation. WIREs Energy Environ. 2015, 4, 196-211. [CrossRef]

7. Kirchhoff, H.; Kebir, N.; Neumann, K.; Heller, P.W.; Strunz, K. Developing mutual success factors and their application to swarm electrification: Microgrids with $100 \%$ renewable energies in the Global South and Germany. J. Clean. Prod. 2016, 128, 190-200. [CrossRef]

8. Singh, R.; Wang, X.; Mendoza, J.C.; Ackom, E.K. Electricity (in)accessibility to the urban poor in developing countries. WIREs Energy Environ. 2015, 4, 339-353. [CrossRef] 
9. Gitelman, L.; Gitelman, L.; Kozhevnikov, M. Window of Opportunity for Sustainable Energy. Int. J. Energy Prod. Manag. 2017, 2, 173-185. [CrossRef]

10. Shao, S.; Yang, J.; Tian, X.; Ju, M.; Hyang, L. Integrated Environmental Risk Assessment and Whole-Process Management System in Chemical Industry Parks. Int. J. Environ. Res. Public Health 2013, 10, 1609-1630. [CrossRef] [PubMed]

11. Barreto, L.; Makihira, A.; Riahi, K. The hydrogen economy in the 21st century: A sustainable development scenario. Int. J. Hydrogen Energy 2003, 28, 267-284. [CrossRef]

12. Critical Infrastructure Protection: Threats, Attacks and Countermeasures. Available online: http://www.dis. uniroma1.it/ tenace/download/deliverable/Report_tenace.pdf (accessed on 10 September 2017).

13. Apostolakis, G.E. How useful is quantitative risk assessment? Risk Anal. 2004, 24, 515-520. [CrossRef] [PubMed]

14. Eygelaar, J.; Lötter, D.P.; van Vuuren, J.H. Generator maintenance scheduling based on the risk of power generating unit failure. Int. J. Electr. Power Energy Syst. 2018, 95, 83-95. [CrossRef]

15. MacDougall, S.L. Confronting the financing impasse: Risk management through internationally staged investments in tidal energy development. Int. J. Mar. Energy 2017, 18, 78-87. [CrossRef]

16. Brezhnev, E.; Kharchenko, V.; Manulik, V.; Leontiev, K. Critical Energy Infrastructure Safety Assurance Strategies Considering Emergent Interaction Risk. In Advances in Dependability Engineering of Complex Systems; Springer: Cham, Switzerland, 2018; pp. 67-78.

17. Cai, Y.P.; Huang, G.H.; Yang, Z.F.; Tan, Q. Identification of optimal strategies for energy management systems planning under multiple uncertainties. Appl. Energy 2009, 86, 480-495. [CrossRef]

18. Fischhoff, B.; Watson, S.R.; Hope, C. Defining Risk. Policy Sci. 1984, 17, 123-139. [CrossRef]

19. Torretta, V.; Rada, E.C.; Schiavon, M.; Viotti, P. Decision support systems for assessing risks involved in transporting hazardous materials: A review. Saf. Sci. 2017, 92, 1-9. [CrossRef]

20. Aghaei, J.; Charwand, M.; Gitizadeh, M.; Heidari, A. Robust Risk Management of Retail Energy Service Providers in Midterm Electricity Energy Markets under Unstructured Uncertainty. J. Energy Eng. 2017, 143, 04017030. [CrossRef]

21. Dahlgren, R.; Liu, C.-C.; Lawarrée, J. Risk assessment in energy trading. IEEE Trans. Power Syst. 2003, 18, 503-511. [CrossRef]

22. Gountis, V.P.; Bakirtzis, A.G. Bidding Strategies for Electricity Producers in a Competitive Electricity Marketplace. IEEE Trans. Power Syst. 2004, 19, 356-365. [CrossRef]

23. Gitelman, L.D.; Kozhevnikov, M.V. Energy Strategies of Industrial Enterprises. WIT Trans. Ecol. Environ. 2015, 192, 297-307. [CrossRef]

24. Dimitrova, A.; Egenhofer, C.; Behrens, A. A Roadmap to Enhanced Regional Energy Policy: Cooperation in South East Europe. Available online: http:/ / aei.pitt.edu/74256/1/SR134_Roadmap_SEE.pdf (accessed on 10 September 2017).

25. Davidson, R.K. Cultural Impacts on Occupant Behaviour and Energy Efficiency. Int. J. Energy Prod. Manag. 2017, 2, 186-195. [CrossRef]

26. Kern, F.; Smith, A. Restructuring energy systems for sustainability? Energy transition policy in the Netherlands. Energy Policy 2008, 36, 4093-4103. [CrossRef]

27. Operational Risk Management in the Energy Industry. Available online: https:/ /www.managementsolutions. com/sites/default/files/publicaciones/eng/Operational-Risk-Energy.pdf (accessed on 2 October 2017).

28. Risk Intelligence in the Energy \& Resources Industry. Enterprise Risk Management Benchmark Survey. Available online: https:/ / www2.deloitte.com/content/dam/Deloitte/uy / Documents/energy-resources / 34215A\%20ERM\%20Survey\%20Hi.pdf (accessed on 2 October 2017).

29. Risk Management in the Electricity Industry — White Paper I-Overall Perspective. Available online: http: / / www.eurelectric.org/media / 42893/whitepaperioverallperspectivefinal-2007-030-0137-2-.pdf (accessed on 2 October 2017).

30. European Power \& Utilities Report. 2017. Available online: https://assets.kpmg.com/content/dam/kpmg/ xx/pdf/2017/08/euro-power-and-utilities.pdf (accessed on 2 October 2017).

31. The Future of the Global Power Sector. Preparing for Emerging Opportunities and Threats. Available online: https:/ / www2.deloitte.com/global/en/pages/energy-and-resources/articles/future-ofglobal-power-sector.html (accessed on 2 October 2017). 
32. 2017 Power and Utilities Industry Trends. Managing a Revenue Downturn While Meeting the Demands of Consumers. Available online: https:/ / www.strategyand.pwc.com/media/file/2017-Power-and-UtilitiesIndustry-Trends.pdf (accessed on 2 October 2017).

33. Delphi Energy Future 2040. Delphi-Study on the Future of Energy Systems in Germany, Europe and the World by the Year 2040. Available online: http://www.pwc.com/gx/en/energy-utilities-mining/pdf/ delphi-energy-future.pdf (accessed on 2 October 2017).

34. Risk Management for Asset Management. Ernst \& Young Survey 2010. Available online: http:/ / www.vaioe.at/fileadmin/user_upload/tax_legal/Klassische_Fonds/Allgemeine_Informationen/ 2010/Risk_Management_for_Asset_Management_-_Ernst__Young_Survey_2010.pdf (accessed on 2 October 2017).

35. Stafforda, B.A.; Wilson, E.J. Winds of change in energy systems: Policy implementation, technology deployment, and regional transmission organizations. Energy Res. Soc. Sci. 2016, 21, 222-236. [CrossRef]

36. Ota, U.; Taniguchi, H.; Nakajima, T.; Liyanage, K.M.; Baba, J.; Yokoyama, A. Proposal of Smart Storage for Ubiquitous Power Grid. IEEJ Trans. Power Energy 2010, 11, 989-994. [CrossRef]

37. Coping with the Energy Challenge. The IEC's Role from 2010 to 2030. Smart Electrification-The Key to Energy Efficiency. White Paper. 2010. Available online: http:/ /www.iec.ch/smartenergy/pdf/white_paper_lres.pdf (accessed on 10 September 2017).

38. Scholten, D.; Künneke, R. Towards the Comprehensive Design of Energy Infrastructures. Sustainability 2016, 8, 1291. [CrossRef]

39. Tillet, A.; Locke, J.; Mencias, J. National Energy Policy Framework "Energy By the People ... For the People". 2011. Available online: https://www.iea.org/media/pams/belize/EnergyPolicyFramework.pdf (accessed on 10 September 2017).

40. Riazi, M.; Hosseyni, S.M. Overview of current energy policy and standards in the building sector in Iran. WIT Trans. Ecol. Environ. 2011, 150, 189-200. [CrossRef]

41. Onat, N.C.; Kucukvar, M.; Halog, A.; Cloutier, S. Systems Thinking for Life Cycle Sustainability Assessment: A Review of Recent Developments, Applications, and Future Perspectives. Sustainability 2017, 9, 706. [CrossRef]

42. Zame, K.K.; Brehm, C.A.; Nitica, A.T.; Richard, C.L.; Schweitzer, G.D., III. Smart grid and energy storage: Policy recommendations. Renew. Sustain. Energy Rev. 2017, 82, 1646-1654. [CrossRef]

43. Risk Quantification and Risk Management in Rennewable Energy Projects. Available online: http://iea-retd. org/wp-content/uploads /2011/11/RISK-IEA-RETD-2011--6.pdf (accessed on 2 October 2017).

44. Späth, P. Understanding the Social Dynamics of Energy Regions-The Importance of Discourse Analysis. Sustainability 2012, 4, 1256-1273. [CrossRef]

45. Auth, K.; Konold, M.; Musolino, E.; Ochs, A. Caribbean Sustainable Energy Roadmap (C-SERMS), Phase 1 Summary and Recommendations for Policymakers. Available online: http:/ / www.worldwatch. org/system/files/nPhase\%201\%20C-SERMS\%20Summary\%20for\%20Policymakers\%20(1).pdf (accessed on 10 September 2017).

46. Ranisau, J.; Barbouti, M.; Trainor, A.; Juthani, N.; Salkuyeh, Y.K.; Maroufmashat, A.; Fowler, M. Power-to-Gas Implementation for a Polygeneration System in Southwestern Ontario. Sustainability 2017, 9, 1610. [CrossRef]

47. Ragazzi, M.; Ionescu, G.; Cioranu, S.I. Assessment of Environmental Impact from Renewable and Non-renewable Energy Sources. Int. J. Energy Prod. Manag. 2017, 2, 8-16. [CrossRef]

48. Anisimov, I.; Magaril, E.; Magaril, R.; Chikishev, E.; Chainikov, D.; Gavaev, A.; Ertman, S.; Ertman, Y.; Ivanov, A. Improving vehicle adaptability to the operating conditions of «smart» cities in the northern regions. E3S Web Conf. 2016, 6, 02003. [CrossRef]

49. Jänicke, M. Ecological Modernisation: new perspectives. J. Clean. Prod. 2008, 16, 557-565. [CrossRef]

50. International Energy Agency (IEA). $\mathrm{CO}_{2}$ Emissions from Fuel Combustion; International Energy Agency (IEA): Paris, France, 2016.

51. Golusin, M.; Popov, S.; Dodic, S. Sustainable Energy Management; Elsevier: Boston, MA, USA, 2013; pp. 141-210.

52. Gitelman, L.D.; Isayev, A.; Gavrilova, T.; Gamburg, A.; Gitelman, L.M.; Yeliseyeva, K.; Zorin, N.; Kozhevnikov, M.; Kostina, G.; Rostik, O.; et al. Methodology of Innovative Management Education; Ekonomika Publishing House: Moscow, Russia, 2015; pp. 53-65. 
53. Tools and Concepts for Local Energy Planning. Available online: https://ec.europa.eu/energy/intelligent/ projects / sites/iee-projects / files / projects/documents/easy_tools_and_concepts_for_local_energy_ planning_en.pdf (accessed on 10 September 2017).

54. Deming, W.E. Out of the Crisis, Center for Advanced Engineering Study; Massachusetts Institute of Technology: Cambridge, MA, USA, 1982.

55. Vishnevskiy, K.; Karasev, O.; Meissner, D. Integrated roadmaps for strategic management and planning. Technol. Forecast. Soc. Chang. 2016, 110, 153-166. [CrossRef]

56. D'Sa, A. Integrated resource planning (IRP) and power sector reform in developing countries. Energy Policy 2005, 33, 1271-1285. [CrossRef]

57. Shrestha, R.M.; Marpaung, C.O.P. Integrated resource planning in the power sector and economy-wide changes in environmental emissions. Energy Policy 2006, 34, 3801-3811. [CrossRef]

58. Hu, Z.; Wen, Q.; Wang, J.; Tan, X.; Nezhad, H.; Shan, B.; Han, X. Integrated resource strategic planning in China. Energy Policy 2010, 38, 4635-4642. [CrossRef]

59. Funabashi, T. Integration of Distributed Energy Resources in Power Systems; Academic Press: Nagoya, Japan, 2016; pp. 15-50.

60. Wilson, R.; Biewald, B. Best Practices in Electric Utility Integrated Resource Planning. Examples of State Regulations and Recent Utility Plans. Available online: http:/ /www.raponline.org/wp-content/uploads / 2016/05/rapsynapse-wilsonbiewald-bestpracticesinirp-2013-jun-21.pdf (accessed on 10 September 2017).

61. Birkmann, J.; Buckle, P.; Jaeger, J.; Pelling, M.; Setiadi, N.; Garschagen, M.; Fernando, N.; Kropp, J. Extreme events and disasters: A window of opportunity for change? Analysis of organizational, institutional and political changes, formal and informal responses after mega-disasters. Nat Hazards 2010, 55, 637-655. [CrossRef]

62. Tyler, C.F. HAZOP: Guide to Best Practice, 3rd ed.; Elsevier: Amsterdam, The Netherlands, 2015; pp. 10-28.

63. Regional Energy Markets: Do Inconsistent Governance Structures Impede U.S. Market Success? Available online: https://e4thefuture.org/wp-content/uploads/2016/07/RTO-Governance-2016.pdf (accessed on 10 September 2017).

64. Regional Energy Deployment System (ReEDS) Model Documentation: Version 2016. Available online: https: / / www.nrel.gov / docs/fy17osti/67067.pdf (accessed on 10 September 2017).

65. Clarke, L.; Krey, V.; Weyant, J.; Chaturvedi, V. Regional energy system variation in global models: Results from the Asian Modeling Exercise scenarios. Energy Econ. 2012, 34, S293-S305. [CrossRef]

66. Linking Global and Regional Energy Strategies. Available online: http://www.ntnu.no/documents/ 7414984/202064323/LINKS+folder_engelsk_small+4+sider.pdf/4f55804b-bfbb-4613-9462-4fd054d89f05 (accessed on 10 September 2017).

67. Gitelman, L.D.; Ratnikov, B.E.; Kozhevnikov, M.V. Demand-side management for energy in the region. Econ. Reg. 2013, 2, 78-84. [CrossRef]

68. Kozhevnikov, M. Approaches To The Formation Of Energy Service Markets In Developing Countries. WIT Trans. Ecol. Environ. 2014, 190, 27-34. [CrossRef]

69. Gitelman, L.D.; Kozhevnikov, M.V. Risks of Systemic Transformation in Energy Companies. WIT Trans. Ecol. Environ. 2015, 192, 357-365. [CrossRef]

(c) 2017 by the authors. Licensee MDPI, Basel, Switzerland. This article is an open access article distributed under the terms and conditions of the Creative Commons Attribution (CC BY) license (http://creativecommons.org/licenses/by/4.0/). 